Andrejs VILKS

Riga Stradins University, Faculty of Law

Riga, Latvia

Andrejs.Vilks@rsu.lv

ORCID 0000-0002-5161-0760

Aldona KIPĀNE

Riga Stradins University, Faculty of Law

Riga, Latvia

aldonakipane@inbox.lv

ORCID 0000-0001-6408-3456

https://doi.org/10.34739/dsd.2019.02.10

\title{
КОРРУПЦИЯ - ПОМЕХА В БОРЬБЕ ПРОТИВ НАРКОТИКОВ
}

\begin{abstract}
АннотАция: В статье дается представление о наркокоррупции как социально-правовом феномене. Цель данной статьи - предоставить криминологическую основу наркокоррупции путем анализа теоретических и практических проблем. Предметом исследования является коррупция как негативное социальное явление, связанное с незаконным оборотом наркотических средств, а также направления профилактики этого явления. Наркокоррупция - это относительно новое криминологическое понятие. Анализ этих феноменов является важным предметом исследования особой части науки криминологии, учитывая, что одной из самых сложных проблем сегодня является предотвращение преступности. Вот почему необходим постоянный криминологический анализ этого негативного явления с выявлением профилактических мер, методов и средств. Основу исследования составляют различные документы, мнения и выводы ученых. В статье используются некоторые методы общенаучного исследования и специальные методы: монографический, логикоконструктивный метод, логическая интерпретация, статистические методы и метод интерпретации правовых норм.
\end{abstract}

КЛЮЧЕВЫЕ СЛОВА: коррупция, незаконный оборот наркотических средств, наркокоррупция, предотвращение

\section{THE CORRUPTION AS AN OBSTACLE IN THE FIGHT AGAINST DRUGS}

\begin{abstract}
The article provides an insight into drug-related corruption as a social legal phenomenon. The aim of the article is to provide the criminological framework of drug-related corruption by analyzing theoretical and practical problems. The subject of the study is corruption as a negative social phenomenon related to the illicit trafficking in narcotic drugs, as well as directions of prevention of this phenomenon. Drug-related corruption is a relatively new criminological concept. Taking into consideration that one of the most difficult problems today is the prevention of crime, analysis of these phenomena is an important subject of research within
\end{abstract}


criminology. Therefore, constant criminological analysis of this negative phenomenon is necessary by identifying preventive measures, methods and measures. The content of various documents, opinions and scientists' perspectives form the basis for this research. The authors used several methods of general scientific research and the following specific methods: monographic, logically constructive method, logical interpretation, statistical methods and method of interpretation of legal norms.

KEYWORDS: corruption, illicit traffic in narcotic drugs, drug-related corruption, prevention

\section{ВВЕДЕНИЕ}

В мировой криминологии в процессе изучения коррупции как социально-правового явления удалось накопить значительный объем информации. Преступность - явление не только социально-правовое (криминологическое), но и финансово-экономическое. Экономическое исследование феномена коррупции фактически началось в семидесятых годах двадцатого столетия с работы С. Роз-Аккерман, в которой коррупция рассматривалась как экономическое поведение в условиях риска, связанного с совершением преступления и возможным наказанием за него. Следует отметить, что в настоящее время коррупция является особой и опасной социальной болезнью для многих стран в мире. В каждой стране коррупция принимает различные формы и масштабы. Подсчитано, что экономике ЕС коррупция обходится в 120 миллиардов евро в год, что немногим меньше годового бюджета EC. Поэтому борьба с коррупцией способствует росту конкурентоспособности ЕС в мировой экономике ${ }^{1}$.

Исторические факты свидетельствуют о том, что коррупция стара как мир, и структуры власти теснейшим образом связаны с возникновением данного явления. Коррупция сопровождает человечество с древнейших времен. Наказание за взяточничество (подкуп) предусматривалось законами Хаммурапи (четыре тысячи лет назад), как и предписаниями, установленными египетскими фараонами․

Коррупция многолика и разнообразна.По уровню распространения коррупционных отношений можно выделить - низовую (в низшем и в среднем эшелонах власти), верхушечную (высших чиновников и политиков), международную (в сфере мирохозяйственных отношений). Транснациональная организованная преступность, коррупция и терроризм по-прежнему создают по всему миру серьезные угрозы для безопасности, развития и устойчивого управления. Наркотики порождают опасность для миллионов людей, становятся причиной увеличения уровня смертности и вызывают серьезное ослабление социальной сплоченности и истощение социального капитала. Как указывается в подготовленном Организацией Объединенных Наций Всемирном докладе

\footnotetext{
1 IeskatsEiropasSavienībaspolitikā EScīṇapretkrāpšanuunkorupciju. Luksemburga: Eiropas Savienības Publikāciju birojs, 2015, 4. lpp.

2 Я.И. Гилинский, Коррупщия: теория, российская реальность, социиальный контроль, Криминология: вчера, сегодня, завтра. Труды Санкт-Петербургского криминологического клуба, Бишкек 2003, № 1(6), с. 239.
} 
о наркотиках за 2018 год, от расстройств, связанных с потреблением наркотиков страдает более 31 миллиона человек ${ }^{3}$. Существующая коррупция создаёт реальную угрозу не только для системы государственного управления, финансовой сферы, но и общественной безопасности и состояния общественного здоровья. Коррупция в сфере наркотических веществ создаёт объективные условия для распространения наркомании, увеличению объёма наркотических средств и количества потребителей психоактивных веществ.

Под самим термином “коррупция” большинство юристов и политиков подразумевают корыстное использование своего положения в обществе в личных целях. Таким образом, коррумпированным может быть, как бюрократ в отделе государственных закупок, в том числе ответственный за приобретение специальной техники для уголовной полиции или таможни (тогда говорят о так называемой государственной коррупции), так и политический деятель (политическая коррупция), а также менеджер частной фирмы, закупающий и распространяющий психоактивные вещества - медикаментозные препараты, нарушая нормативные акты (коррупция в частном секторе). Коррупционер продает не принадлежащую ему собственность или оказывает услугу за взятку, которая может выражаться или в денежной форме, или в виде “подарка", или как предоставление дополнительного вознаграждения, или как благосклонность к родственникам и т.п.

Коррупция является сложным систематическим негативным социальным явлением, которое зависит от сложившихся в государстве традиций, национального сознания, и прошло собственный уникальный исторический путь развития. Экскурс в историю Латвии показывает, что влияние на должностные лица посредством материальных благ на землях нынешней территории Латвии было описано уже в средние века. В «Ливонской хронике Индрика» (Heinrici Cronicon Lyvoniae, 1225-27) упомянуты события 1199 года, когда собрание старейшин ливов решило казнить немецких священников и торговцев, которые останутся на земле ливов. Однако и торговцы, и священники спасли свои жизни, подарив подарки старейшинам ${ }^{4}$.В настоящее время большая часть общества считает, что в Латвии уровень коррупции следует оценивать как высокий. В опросе Евробарометра, проведенном в 2017 году, 84\% респондентов заявили, что коррупция широко распространена в Латвии. Коррупциястала проблемой в Латвийской Республике уже после создания первого Латвийского независимого государства, когда в стране возникла сумятица, которую можно было использовать для получения личной выгоды ${ }^{5}$.

Коррупция дезорганизует общество, создает ситуации отчуждения личности от государства, люди теряют надежду на мудрую, честную и ответственную государственную власть.Коррупция ставит под угрозу стабильность и безопасность государств, подрывает деятельность учреждений, основные ценности демократии, этики и справедливости

\footnotetext{
${ }^{3}$ Контроль над НАРКОТИКАМИ, предупреждение ПРЕСТУПНОСТИ и борьба с ТЕРРОРИЗМОМ. https://www.un.org/annualreport/files/2019/09/Annual-report-SG-2019-RU-Chapter-8.pdf (23.10.2019).

${ }^{4}$ Korupcijas vēsturiskais pārskats. Nacionālā enciklopēdija. https://enciklopedija.lv/skirklis/35090 (24.10.2019).

${ }^{5}$ A. Vilks, K. Ķipēna, Korupcija. Mācību grāmata juridiskajām augstskolām un fakultetem, Rīga 2000, c. 17.
} 
и подвергает риску долгосрочное развитие и верховенство закона ${ }^{6}$. Коррупцияявляется главным препятствием для экономического и социального развития, поэтому УНП ООН сотрудничает с общественными и частными организациями и гражданским обществом, чтобы ослабить влияние коррумпированных лиц на правительство, национальные границы и торговые каналы. За последние годы Управление усилило деятельность по оказанию помощи государствам по восстановлению активов, украденных коррупционерами ${ }^{7}$.Целью коррупции в сфере государственной службы является, прежде всего, обогащение отдельных лиц за счет взаимодействия с преступным элементом, в том числе с наркомафией. Наркобизнес, в свою очередь, не мог бы существовать, и, тем более развиваться, если бы не тесная, тайная, а порой, и открытая связь между политическими деятелями и преступным элементом.

Криминологические исследования показывают, что незаконный оборот наркотиков и коррупция - тесно взаимосвязанные явления. Точное сравнение дал профессор М.П. Клейменов, указав, что коррупция тесно связана с мафиозными отношениями, так же как дыхание с жизнью ${ }^{8}$. Наркобизнес является одной из наиболее прибыльных отраслей теневой экономики. Высокие доходы, приносимые этим видом преступной деятельности, активно используются преступниками для подкупа работников правоохранительных органов, позволяющих им безнаказанно пересекать границы государств, распространять наркотики среди населения нашей страны, уходить от ответственности ${ }^{9}$.Основной целью деятельности вовлеченных в наркокоррупцию лиц является получение обоюдной выгоды получение наркотических средств, значительной прибыль от распространения, хранения или от транспортировки наркотиков и т.п., а также выгоды в форме взяток. Чем больше наркодилер распространяет наркотики, тем больше размер доходов наркокоррупционеров. Наркокоррупция создаёт благоприятные условия не только для расширения незаконного оборота наркотиков, в том числе на транснациональном уровне, но и деформирует сферу государственного управления, способствует деградации части населения, в основном, молодёжи, которая вовлечена в употребление наркотиков. Однако в начале все же определим, что подразумевается под основными понятиями, которыми мы оперируем.

\section{ПОНЯТИЕ КОРРУПЦИИ}

Существует множество определений понятия коррупции. Мнения ученых по поводу этого существенно отличаются. Понятие коррупции толкуется в широком или в узком понимании. Термин «коррупция» произошел от латинского слова «соrruptio», которое имеет несколько значений: 1) совращение, подкуп (militum T); 2)порча, упадок, коррупция

\footnotetext{
${ }^{6}$ Apvienoto Nāciju Organizācijas Pretkorupcijas konvencija.

${ }^{7}$ Об УНП ООН. https://www.unodc.org/unodc/ru/about-unode/index.html (21.10.2019).

8 М. П. Клейменов, Проблема коррупиии среди сотрудников служббы криминальной милиции/ Преступность в России и борьба с ней: региональный аспект, Москва 2003, с. 8.

${ }_{9}^{9}$ Н. В. Павловская, Коррупиия в сфере противодействия незаконному обороту наркотических средств: монограф,. Москва 2014, с. 184.
} 
(sc. morum T); 3)извращённость, превратность (opinionum $C$ ); 4)расстройство, расшатанность, плохое состояние (corporis $C)^{10}$. Часто исследователи в областикоррупции связывают этимологию слова «коррупция» только со взяточничеством или разложением власти в результате действий третьих лиц, хотя более точный вывод относительно семантического значения термина можно сделать, разделив слово «коррупция» на две части: «cor» (сердце, душа, дух, ум) и «ruptio» (травмы, увечья). Таким образом, в этой интерпретации увечье души, духовная деградация выходят на первый план ${ }^{11}$.

Согласно Макиавелли, коррупция - это использование публичных возможностей в частных интересах. Определения corrumpire в Римском праве понималось как разламывать, портить, разрушать, повреждать, фальсифицировать, подкупать и обозначало противоправное действие, например, в отношении судьи. Это понятие произошло от сочетания латинских слов «correi» - несколько участников в одной из сторон обязательственного отношения по поводу единственного предмета, и «rumpere» - ломать, повреждать, нарушать, отменять. В результате образовался термин, который предполагал участие в деятельности нескольких (не менее двух) лиц, целью которых является «порча», «повреждение» нормального хода судебного процесса или процесса управления делами общества.

В Юридическом словаре Блэка коррупция определяется как: 1) преступление, совершенное с целью предоставления преимущества, которое несовместимо с официальными обязанностями должностного лица и правами других лиц; 2) деяние должностного лица, которое незаконно и противоправно использует свое положение или статус в целях достижения благ для себя или для других лиц, противоречащих обязанностям и правам других лиц ${ }^{12}$.

В соответствии с международно-правовыми актами, "коррупция - это злоупотребление государственной властью для получения выгоды в личных целях" ${ }^{13}$.

В соответствии с правовыми актами Совета Европы, коррупция представляет собой взяточничество и любое другое поведение лиц, которым поручено выполнение определенных обязанностей в государственном или частном секторе, и которое ведет к нарушению обязанностей, возложенных на них по статусу государственного должностного лица, частного сотрудника, независимого агента или иного рода отношений и имеет целью получение любых незаконных выгод для себя и других ${ }^{14}$.

Результаты криминологического исследования подтверждают, что коррупция имеет место практически во всех сферах общественной жизни. В этом контексте сфера

\footnotetext{
10 Большой латинско-русский словарь. http://linguaeterna.com/vocabula/list.php?letter=corruptio\&sub $\mathrm{mit}=\% \mathrm{CF} \% \mathrm{EE} \% \mathrm{EA} \% \mathrm{E} 0 \% \mathrm{E} 7 \% \mathrm{E} 0 \% \mathrm{~F} 2 \% \mathrm{FC}(23.10 .2019)$.

${ }^{11}$ A. Kriviňš, Korupcijas novēršana un apkarošana publisko iepirkumu jomāa . Rīga 2015, 18. L.

${ }^{12}$ Black's Law Dictionary. Sixth Edition. St. Paul, MINN, 1990, p. 345.

${ }^{13}$ Vispārējā Pretkorupcijas Stratēǵija. ANO Pretkorupcijas rīku apkopojums. Apvienoto Nāciju Organizācija, Pretkorupcijas rīku apkopojums. 3. izdevums. Vīne: Narkotiku kontroles un noziedzīgu nodarījumu novēršanas birojs, 2004, 10. lpp.

${ }^{14}$ Korupcijas apkarošana Eiropas Savienībā. https://eur-lex.europa.eu/legal-content/LV/TXT/PDF/?uri=CELEX :52011DC0308\&from=LV(24.10.2019.)
} 
предупреждения и борьбы с незаконным оборотом наркотических средств, психотропных веществ и аналогов не является исключением. Термин «наркокоррупция» (англ. narcocorruption) появился в юридическом лексиконе относительно недавно.Российский специалист И.М. Грязнов дает следующее определение в своей диссертации: «Наркокоррупция - этодача (получение) взятки, а также любыеформы и виды соучастия в незаконном обороте наркотиков, совершенные должностными лицами, а также лицами, выполняющими управленческие функции, по мотивам корыстной или иной личной заинтересованности» ${ }^{15}$.

Традиционно различают две формы коррупции: 1) подкуп должностных лиц более низкого уровня; 2) подкуп высокопоставленных чиновников. По степени централизации коррупционных отношений различают такие формы: централизованная (взятки от нижестоящих чиновников передаются вышестоящим);децентрализованная (каждый взяткодатель действует по собственной инициативе).По степени регулярности коррупционных отношений: эпизодическая коррупция;систематическая (институциональная); клептократическая (коррупция как неотъемлемый элемент властных отношений) $)^{16}$.

Наркодельцы используют весь арсенал мер по сохранению и воспроизводству криминального бизнеса, используя преимущественно «тонкие» (ненасильственные) методы воздействия, такие как коррупцию. Преступный бизнес в принципе не заинтересован в открытом противостоянии государственным структурам, ответственным за борьбу с наркобизнесом. Полагаем обоснованным считать, что существование организованной преступности, влечёт за собой возникновение коррупции. Эти явления тесно связаны и не могут существовать друг без друга. Наркокоррупция включает в себя не только просто подкуп представителей государственных структур, но и любые деяния, связанные с оказанием поддержки и развития наркобизнеса. Так, например, в сети розничной торговли героином сотрудники правоохранительных органов осуществляют «прикрытие» торговли на улицах за соответствующее вознаграждение. Кроме того, представители правоохранительных структур сами нередко включаются в этот прибыльный бизнес, реализуя конфискованный ранее героин. Часто для этого используются не только простая материальная зависимость, но и «наркопорабощение» самих сотрудников правоохранительных органов, вовлекаемых в употребление наркотиков $^{17}$. Общественная опасность коррупциина государственном уровне проявляетсяв следующем $\left.{ }^{18}: 1\right)$ неэффективное (нецелевое) распределение и расходование

\footnotetext{
${ }^{15}$ И.М. Грязнов, Преступления, связанные с наркотическими средствами, психотропными вещуествами или их аналогами, совершаемые женщинами: криминологический анализ и уголовно-правовое регулирование: автореф. дис. канд. юрид. Наук, Н. Новгород 2005, с. 112.

16 Т.Б. Качкина, А.В. Качкин, Коррупщия и основные стратегии противодействия ей: учеб, Ульяновск 2010 , с. 19.

17 Наркотики в современном мире: отдельные правовые вопросы, http://ref.rushkolnik.ru/v53737/?page=3 (22.10.2019.).

18 А.Е. Шалагин, Д.Э. Кабиров, Приоритетные направления предупреждения коррупиионной преступности на современном этапе, Вестник КЮИ МВД России № 1 (19) 2015, с. 64.
} 
государственных средств и ресурсов; 2) потеря поступлений от налогов, подрыв налоговойсистемы государства; 3) уменьшение инвестиций в производство, замедление экономического роста; 4) снижение качества услуг, оказываемых государственными и муниципальными органами;5) расширение теневой экономики инеофициальной занятости населения; 6) рост социального неравенства и напряженности в обществе; 7) коррупция выступает подпиткой организованной и должностной преступности; 8) утрата доверия к государственныморганам и их представителям; 9) снижение (падение) общественной морали и нравственности; 10) повышение уровня безработицы, инфляции, социально-негативных явлений, связанных с преступностью; 11) появление в обществе экстремистских настроений, создание устойчивыхрадикально настроенных групп и организаций.

\section{ПРИЗНАКИ КОРРУПЦИИ}

Безусловно, коррупция (как общая, так и наркокоррупция) обладает собственными специфическими признаками и критериями диагностики. Среди них мы выделим:

- Сознательное подчинение общих интересов государственного деятеля личным интересам.

1. Секретность исполнения решений.

- Присутствие взаимных обязательств между теми, кто принимает государственные решения и теми, кому это выгодно.

- Взаимодействие между теми, кому нужно принятие определенного решения и теми, кто может на принятие такого решения повлиять.

- Попытка скрыть акт коррупции посредством каких-нибудь юридических обоснований.

1. Выполнение двойственных функций - государственных и частных - теми, кто совершает эти акты.

- Непосредственная кража, хищение и присвоение государственной собственности должностными лицами.

- Злоупотребление служебным положением для получения неоправданных личных выгод (льгот, преимуществ) в результате неофициального использования официального статуса.

- Конфликт интересов между общественным долгом и личной корыстью.

- Тесная связь между коррупционерами (должностными лица) и преступной (наркокриминальной) средой.

- Изменение отношений наркопреступных группировок - стремление к сотрудничеству с властью, от полного отрицания, к возможностям в сотрудничестве и создание совместного «бизнеса».

- Образование новых видов транснациональных преступных сообществ, с более тесной связью с органами государственной власти и управления. 
Данные признаки, на наш взгляд, следует считать основными, которые указывают на возможные проявления коррупции и наркокоррупции, однако, их перечень носит открытый характер.

\section{ТЕНДЕНЦИИ В СФЕРЕ НАРКОПРЕСТУПНОСТИ И КОРРУПЦИОГЕННОСТЬ}

Проблему наркопреступности и криминогенности можно анализировать, используя по крайней мере два подхода:

1. анализируя криминальную статистику или результаты эмпирических - выборочных криминологических исследований. Сразу отметим, что подобная криминальная статистика явно недостаточна и не отражает объективных криминальных реалий наркокоррупции. Зачем использовать недостаточные и недостоверные данные? Результатами выборочных исследований на данный момент мы не располагаем. Поэтому данный подход при анализе данного явления применять сложно.

2. анализ отдельных фактов наркокоррупции и их некоторое обобщение. Естественно, что факты неоднородны. Вместе с тем они могут послужить основой для последующей разработки более научно обоснованной методики исследования и дать повод для осмысления проблемы. В социологии данный подход принято обозначать как качественное исследование. Данный подход мы и попытаемся использовать, исследуя тенденции наркопреступности и коррупциогенности сферы борьбы с наркотизмом. Развитию наркомании и наркокриминалитета, на наш взгляд, в первую очередь способствует определенная государственная политика. Нередко именно наркотики, а вернее, прибыль от реализации психоактивных веществ, дает возможность укрепиться соответствующим политическим режимам, удержаться у власти определенной политической элите, получить политикам любого уровня сверхвысокую прибыль.

Анализ рынка кокаина, основного наркотика на рынке США, показал, что глобальный рынок наркоторговли глубоко интегрирован в международные рынки денег, товаров и услуг: центры производства сырья для наркотика - коки - Чапаре или Альто Бене в Боливии или Альто Хуоллага в Перу - связаны с лабораториями по выработке готового кокаина и центрами управления в Колумбии, которые до 1995 года являлись филиалами штаб-квартир Медельинского и Кальийского картелей, которые, в свою очередь, связаны с такими финансовыми центрами, как Майами, Панама, Каймановы острова и Люксембург, с транспортными центрами сетей перевозки кокаина в Мексике, такими, как Тамаулипас или Тихуана, и, наконец, с центрами распределения в основных мегаполисах Америки и Западной Европы. Ни одно из этих мест не может существовать само по себе. Картели и их ближайшие американские и итальянские союзники были бы скоро выброшены из бизнеса без боливийского или перуанского сырья, без швейцарских и германских химикатов, без полулегальных финансовых сетей распределения в Майами, Лос-Анжелесе, Нью-Йорке, Амстердаме, Ла-Корунье. 
Поэтому борьба с наркокоррупцией, информационная аналитика, мониторинг финансовых потоков, отслеживание транспортных коммуникаций, принуждение к замене плантаций коки другими сельхозкультурами странами-производителями - вот сегодняшнее лицо Управления по противодействию наркотикам в США. В государствах Центральной Азии, уяснивших для себя все вышеперечисленные аспекты борьбы с незаконным наркооборотом и осознающих угрозу экспансии «афганского» героина в регион, были созданы аналогичные службы.

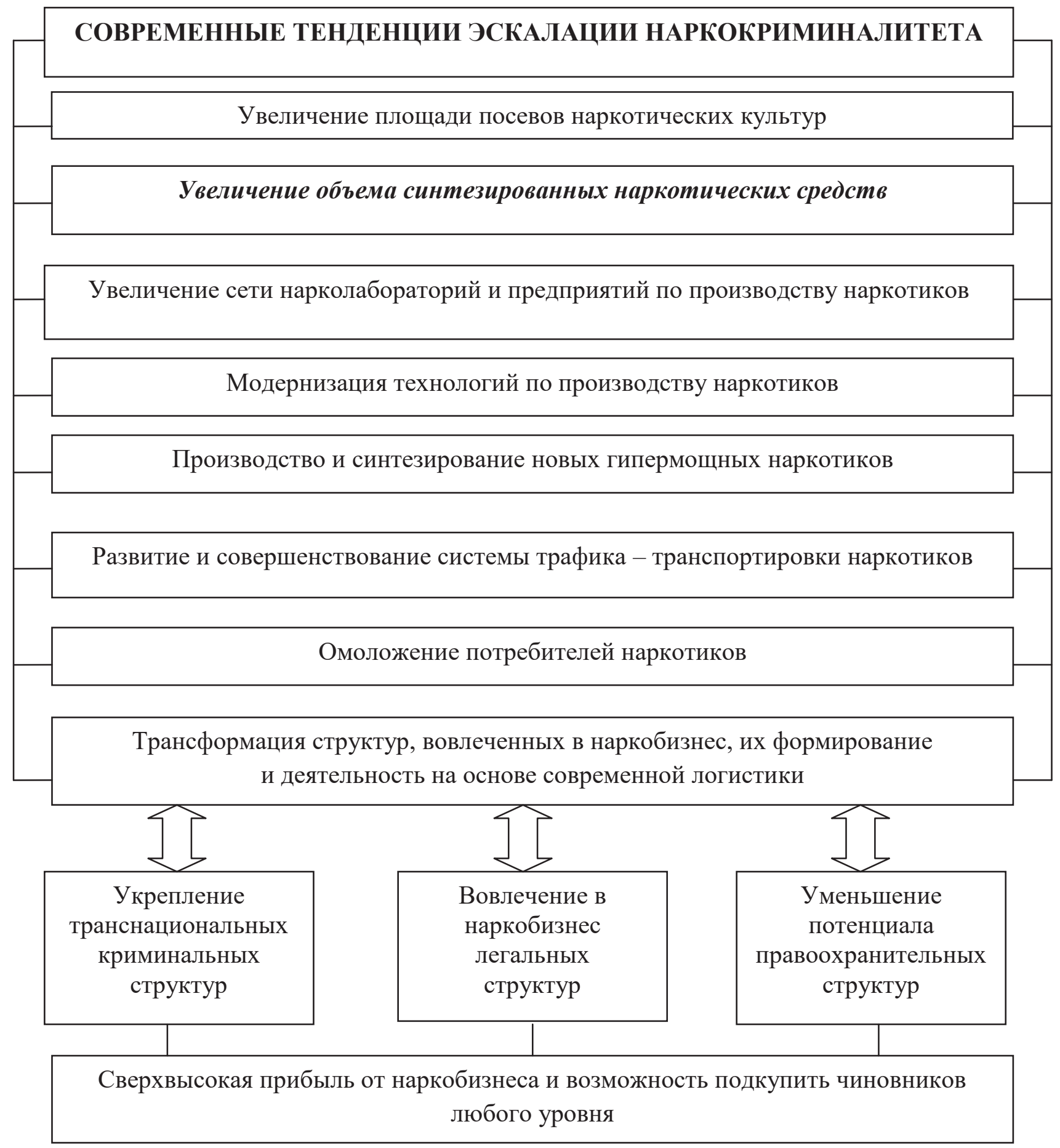

Рис. 1. Наркокриминалитет и коррупция

Источник: собственное исследование. 
Огромные прибыли Медельинского и Кальийского наркокартелей позволяют им использовать для подкупа должностных лиц всех уровней, как в гражданской власти, так и в правоохранительной, абсолютно любые средства, которые недоступны другим отраслям преступного бизнеса по причине рентабельности - как следствие, наркокоррупция стала главной «бедой» государственного механизма США в 60-70-х годах этого столетия.

В настоящее время мы наблюдаем эскалацию наркокриминалитета, что связано с ростом коррупции в правоохранительной сфере и среди частных предпринимателей.

\section{ФАКТОРЫ, ОПРЕДЕЛЯЮЩИЕ НАРКОКОРРУПЦИЮ}

Факторы наркокоррупции можно разделить на несколько уровней.

Во-первых, факторы, в целом обуславливающие преступность и иные правонарушения. К факторам данной группы можно отнести низкий уровень культуры населения, низкий уровень доходов, высокий уровень инфляции и т.д. Данные и иные факторы сказываются как на преступности и правонарушениях в целом, так и обуславливают наркотизацию части населения и, конечно, коррупцию.

Во-вторых, факторы, детерминирующие отдельные группы и виды преступлений. Кданной группе можно отнести факторы, которые, с одной стороны, тесно связаны с наркокриминалитетом, с другой - факторы, которые обуславливают коррупцию. Факторы обеих групп тесно связаны, но, в то же время, они являются весьма специфическими. Так, наркокриминалитет может обуславливать увеличение рынка наркопродукции и расширение спектра предложения психоактивных веществ, недостаточная занятость молодёжи, недостаточный контроль сферы досуга молодёжи и др.

В свою очередь, коррупцию обуславливает другая группа факторов - подбор некомпетентных кадров на определённые должности, недостаточный контроль за их деятельностью, возможность получения ими нерегламентированного вознаграждения (взяток) и т.д.

Третья группа факторов является особой. Данные факторы обуславливают наркокоррупцию и являются наиболее сложными. Они, на наш взгляд, связаны с конкретными факторами в двух взаимосвязанных системах.

Первая система, относится к наркокриминалитету, организованным преступным группам, которые заинтересованы в получении сверхвысокой прибыли и преступных доходов. Наркокоррупцию в данном случае определяют значительные финансовые ресурсы, которые могут быть задействованы для «покупки» работников полиции, прокуратуры, судей, сверхвысоких гонораров адвокатов и т.д. Организованные преступные группы имеют значительные технические и иные ресурсные возможности для проведения экспериментальной работы (покупки услуг учёных), синтезирования и производства наркотиков, их транспортировки ухищрёнными способами, с применением технических приспособлений, формирования широкой сети распространителей 
психоактивных веществ. Необходимо, кроме того, отметить высокую активность, целеустремлённость, динамичность и эластичность действий наркокриминальных групп. Характерно, что участники данных групп находят самые слабые звенья в правоохранительных структурах.

Вторая система относится к субъектам, которые подверглись воздействию наркокоррупции. Данные субъекты - полицейские, прокуроры, судьи, работники тюрем, сотрудники лечебных и фармацевтических учреждений и др. Отметим, что сотрудники, работающие в указанных и иных учреждениях, не обладают необходимым уровнем правового сознания, у них деформированы морально-нравственные нормы, но весьма высок уровень материальных притязаний. Служебная и иная деятельность соответствующих сотрудников недостаточно контролируется. Наряду с указанным, отметим, что структуры, осуществляющие борьбу с наркокриминалитетом, в своей деятельности недостаточно целеустремлены и организационно недостаточно состоятельны. В данной сфере неэффективно ведётся оперативно-поисковая и разведывательная работа, позволяющая предотвратить попытку наркокоррупции.Во многом наркокоррупция объясняется низкой материальной обеспеченностью сотрудников правоохранительных органов (средняя ежемесячная зарплата сотрудника МВД не превышает в среднем 70 долларов США), тогда как непосредственное или опосредованное участие в незаконном обороте наркотиков сулит доход в десятки и сотни раз больше, чем месячное денежное содержание рядового сотрудника полиции. Можно назвать это явление «вынужденной коррупцией», когда государство, не обеспечивая служителей правопорядка достаточной заработной платой, само подталкивает их к нарушениям закона в целях извлечения материальной выгоды.

Огромные доходы, получаемые от оборота наркотиков, позволяют участникам наркобизнеса использовать эти средства на выдвижение «своих людей» в органы государственной власти. На добытые наркосредства приобретается участие в законодательных и исполнительных органах, в управлении регионами, отраслями экономики. Проникновение в государственную власть оставляет практически без надежды тщетные попытки противостоять наркобизнесу той немногочисленной, и пока еще неподкупной части органов управления.

Вовлекаются в незаконную наркодеятельность правоохранительные, судебные и исполнительные органы. За наркоденьги чиновники с готовностью «тормозят» разработку и принятие антинаркотического законодательства, или искажают его до такой степени, что законопроект в итоге получается нежизнеспособным. Выделенная сумма на подкуп чиновника, без колебаний «поступит в карман», и за нее будут работать до последнего, или пока не будет получено более выгодное предложение. И даже если государство бесконечно будет повышать заработную плату своим служащим, специфика человеческих потребностей такова, что много денег или других материальных благ не 
бывает. А наркобароны без проблем поднимут ту нужную для подкупа планку денег, которая, в любом случае будет выше предложенной государством.

Проблема наркокоррупции связана с крайне высокой прибылью, которую получают наркодельцы и коррумпированные чиновники. Ни для кого не секрет, что производство распространение наркотиков - самый окупаемый бизнес. Приведём некоторые конкретные цифры, например, стоимость 1 кг героина:

- в Афганистане составляет 9000 \$;

- в Таджикистане - 25000 \$;

- в Москве - 150000 \$.

В целом основные факторы наркокоррупции можно представить в виде схемы - см. рис. 2.

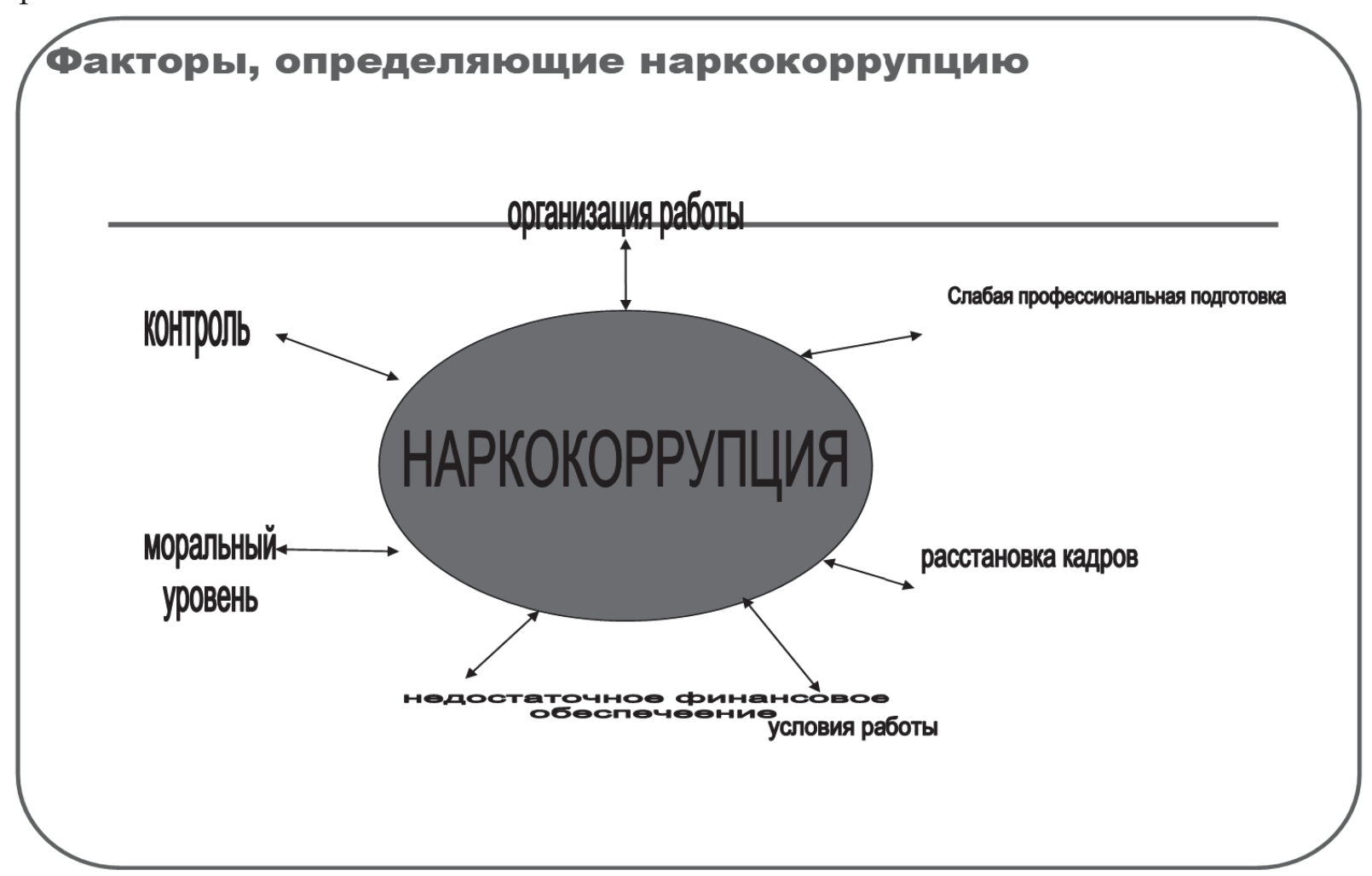

Рис. 2. Факторы наркокоррупции

Источник: собственное исследование.

\section{ВИДЫ И ФОРМЫ КОРРУПЦИИ И НАРКОКОРРУПЦИИ}

Коррупция и наркокоррупция многогранны и разнообразны, как сама жизнь. Ее можно представить, как своеобразную иерархическую модель, как пирамиду, в которой имеются строго определенные уровни и в каждом из них царят свои нормы и характерны специфические модели поведения - смотрите рис. 3. На высших уровнях наркокоррупционной пирамиды располагается политическая элита, государственные чиновники высшего уровня, которые безусловно взяток в обычном виде не берут. Характер их коррупционной деятельности тоже весьма специфичен. 
На данном уровне определяется законотворческий процесс - принятие или непринятие законов, или иных нормативных актов, направленных на эффективную борьбу с наркокриминалитетом, принятие или непринятие программ предупреждения наркомании, обеспечение программ необходимыми финансовыми или техническими ресурсами, организация менеджмента программ и контроля их выполнения. Можно воспрепятствовать принятию закона и получить за данные действия одноразовое вознаграждение, которое измеримо суммами с шестью и более цифрами. Чиновники и должностные лица на низших уровнях данной пирамиды (рядовые полицейские получают взятки или иные вознаграждения гораздо менее впечатляющие, но данный недостаток они компенсируют частотой получения вознаграждения или сами начинают заниматься запрещённой законом деятельностью - распространением наркотиков, стремясь тем самым восстановить нелегитимную «справедливость»).

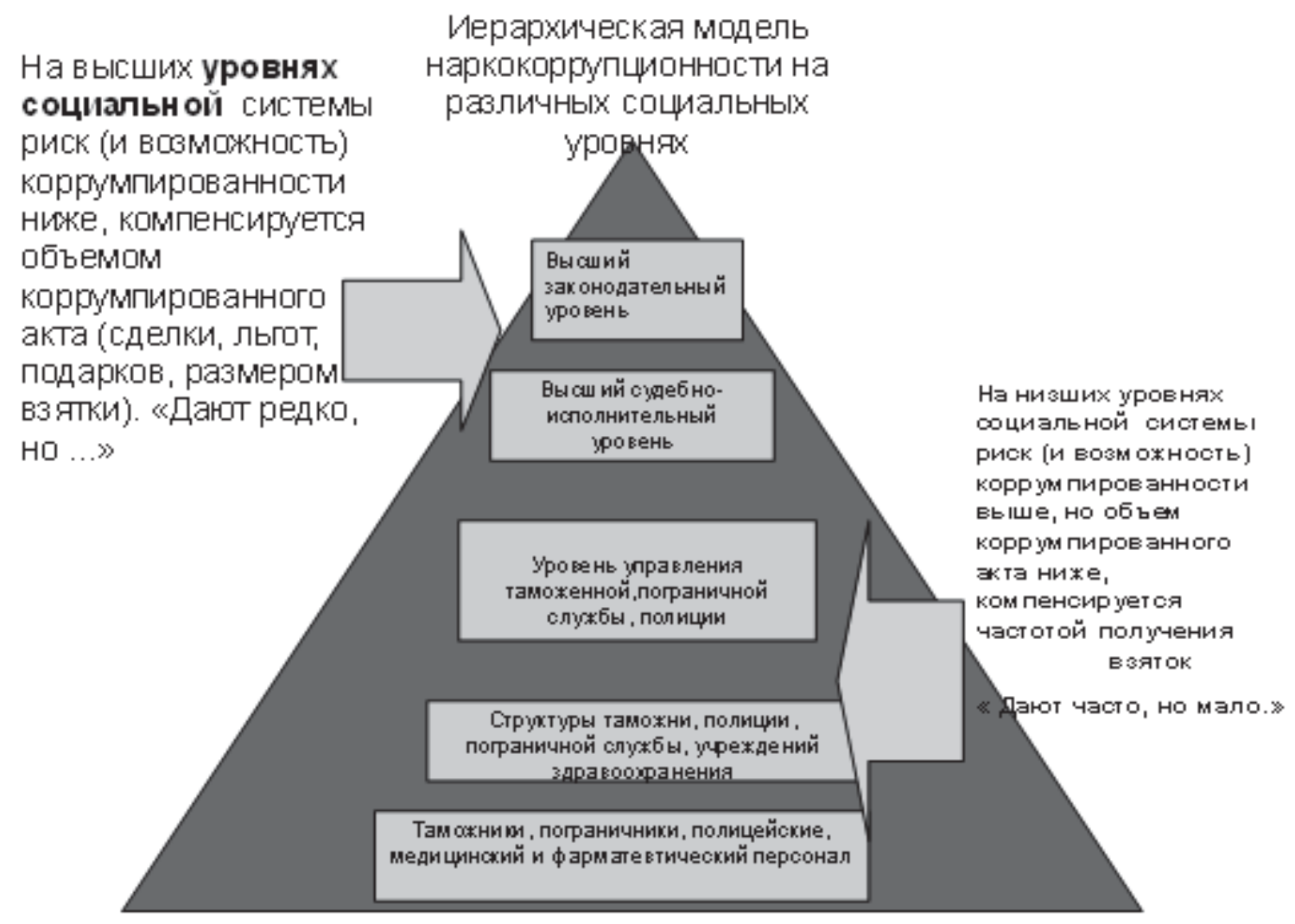

Рис. 3. Пирамида наркокоррупции

Источник: собственное исследование.

На высших уровнях пирамиды наркокоррупции мы можем наблюдать:

- Захват государства - покупка влиятельными (финансовыми, экономическими, криминальными и др.) элементами решений государственных органов или государственных чиновников. Виды захвата государства, которые могут быть связаны коррупцией в области наркотических веществ:

- Захват парламента (формирование послушного, «карманного» депутатского корпуса, предоставление парламентариям льгот и соответствующих должностей). 
- Захват верховной исполнительной власти (кабинетов и советов министров, бюро премьеров, министерств).

- Принятие неэффективных решений в борьбе с наркоманией.

- Необеспечение принятых законов, правительственных решений, государственных и межгосударственных программ необходимыми ресурсами (кадровыми, техническими и техногенными, финансовыми, материальными) - реализация программ борьбы с наркоманией на бумаге.

\section{ВЫводы}

1. Наркокоррупция - это существующее криминологическое явление, которое определяется сложными и иерархическими факторами. Авторы дают следующее объяснение наркокоррупции: наркокоррупция - это состояние коррупции или коррупционного поведения, которое выражается в форме злоупотребления полномочиями должностного лица в сфере предотвращения и борьбе с незаконным оборотом наркотических средств и психотропных веществ, с целью получения материальных благ и других благ или иного рода преимуществ.

2. Правовое воздействие на наркокоррупцию должно быть ориентировано на оба направления: предупреждение и борьба с наркокоррупцией. Организациям, ведущим борьбу с наркоторговлей, одновременно следует решительно пресекать коррупцию. Этот вопрос требует комплексного подхода и должен быть отражен в программах и стратегиях противодействия незаконному обороту наркотических средств, а соответствующие правоохранительные органы должны обеспечить практику выявления и наказания наркокоррупционеров. При этом борьба с наркокоррупцией, наряду с организационными, экономическими и иными средствами, требует использования правовых механизмов для снижения коррупционного потенциала правового статуса должностных лиц в сфере контроля наркотиков.

3. Важно прогнозировать тенденции развития криминальных ситуаций. Необходимо прогнозирование рисков наркокоррупции. Криминологический прогноз показывает, что злоупотребление наркотиками в ближайшие годы будет расти, что негативно скажется на международной ситуации.

\section{ЛИТЕРАТУРА}

Anatolijs Kriviņš. Korupcijas novēršana un apkarošana publisko iepirkumu jomā. 2015. Rīga: SIA "Drukātava".

Andrejs Vilks, Kristīne Ķipēna. 2000. Korupcija. Mācību grāmata juridiskajām augstskolām un fakultātēm. Rīga: Lietišķās informācijas dienests.

Black's Law Dictionary. Sixth Edition. 1990. St. Paul, MINN: West Publishing Co.

Ieskats Eiropas Savienības politikā ES cīņa pret krāpšanu un korupciju. Luksemburga: Eiropas Savienības Publikāciju birojs, 2015. 
Korupcijas apkarošana Eiropas Savienībā. https://eur-lex.europa.eu/legal-content/LV/TXT/ PDF/?uri=CELEX:52011DC0308\&from $=$ LV.

Korupcijas vēsturiskais pārskats. Nacionālā enciklopēdija. https://enciklopedija.lv/skirklis/ 35090.

Vispārējā Pretkorupcijas Stratēgija. ANO Pretkorupcijas rīku apkopojums. Apvienoto Nāciju Organizācija, Pretkorupcijas rīku apkopojums. 3. izdevums. Vīne: Narkotiku kontroles un noziedzīgu nodarījumu novēršanas birojs, 2004, 10. lpp.

Антон Шалагин, Дмитрий Кабиров. 2015. "Приоритетные направления предупреждения коррупционной преступности на современном этапе”. Вестник КЮИ МВД России №1 (19): 63-67 [Anton Shalagin, Dmitrij Kabirov. 2015. „Priorytetnyje napravlenija preduprezhdenija korruptsionnoj prestupnosti na sovremennom etape”. Vestnik KJUI MVD Rossi №1 (19): 63-67].

Большой латинско-русский словарь. http://linguaeterna.com/vocabula/ list.php?letter=corru ptio\&submit $=\% \mathrm{CF} \% \mathrm{EE} \% \mathrm{EA} \% \mathrm{E} 0 \% \mathrm{E} 7 \% \mathrm{E} 0 \% \mathrm{~F} 2 \% \mathrm{FC} . \quad[$ Bol'shoj latinsko-russkij slovar', http://linguaeterna.com/vocabula/list.php?letter $=$ corruptio\&submit $=\% \mathrm{CF} \% \mathrm{EE}$ $\% \mathrm{EA} \% \mathrm{E} 0 \% \mathrm{E} 7 \% \mathrm{E} 0 \% \mathrm{~F} 2 \% \mathrm{FC}]$.

Игорь Грязнов. 2005. Преступления, связанные с наркотическими средствами, психотропными веществами или их аналогами, совершаемые женщинами: криминологический анализ и уголовно-правовое регулирование: автореф. дис. канд. юрид. наук. Н. Новгород [Igor' Grjaznov. 2005. Prestuplenija, svjazannyje c narkoticheskimi sredstvami, psikhotropnymi veshchestvami ili ikh analogami, covershaemyje zhenshchinami: kriminologicheskij analiz i ugolovno-pravovoe regulirovanije: avtoref. dis. kand. jurid. nauk. N. Novgorod].

Контроль над НАРКОТИКАМИ, предупреждение ПРЕСТУПНОСТИ и борьба с ТЕРРОРИЗМОМ. https://www.un.org/annualreport/files/2019/09/Annual-report-SG2019-RU-Chapter-8.pdf (23.10.2019.) [Kontrol' nad NARKOTIKAMI, preduprezhdenije PRESTUPNOSTI i bor'ba c TERRORIZMOM. https://www.un.org/annualreport/files/ 2019/09/Annual-report-SG-2019-RU-Chapter-8.pdf].

Михаил Клеймёнов. 2003. Проблема коррупции среди сотрудников службы криминальной милиции. W. Преступность в России и борьба с ней: региональный аспект. С. 9-16. Москва: Российская криминологическая ассоциация [Mikhail Klejmjonov. 2003. Problema korruptsii sredi sotrudnikov sluzhby kriminal'noj militsii. V. Prestupnost' v Rossi i bor'ba s niej: regional'nyj aspekt. C. 9-16. Moskva: Rossijskaja kriminologicheskaja assotsijatsija].

Надежда Павловская. 2014. Коррупция в сфере противодействия незаконному обороту наркотических средств: монографи. Москва: Акад. Ген. прокуратуры Рос. Федерации [Nadezhda Pavlovskaja. 2014. Korruptsija v sfere pritovodejstvija nezakonnomu oborotu narkotichestkikh sredstv: monografi. Moskva: Akad. Gen. Prokuratury Ros. Federatsii]. 